\title{
Effectiveness Test of Tools (Wire Steel) toward Forwarding Somersault Skills
}

\author{
Sani Gunawan ${ }^{1}$, Fegie Rizkia Mulyana ${ }^{2}$, Ridwan Gumilar ${ }^{3}$ \\ \{sanigunawan@unsil.ac.id ${ }^{1}$, fegierizkiamulyana@unsil.ac.id ${ }^{2}$,ridwangumilar@unsil.ac.id ${ }^{3}$ \} \\ Siliwangi University, Tasikmalaya, Indonesia ${ }^{123}$
}

\begin{abstract}
This study aims to determine the effectiveness of tool for somersault skills. Another purpose of this research is to be used as teaching material and methods on how to provide assistance effectively and efficiently when teaching gymnastics. The basic thing that underlies this research is to enrich science through research in the field of teaching, especially on the floor gymnastics course. This research uses the Quasi Experiment research method, while the research design uses Nonequivalent Control Group Design. Data analysis in this study used the normality test and homogeneity test, followed by an t-test to test the research hypothesis. From the results of data processing and analysis and hypothesis testing, it was concluded that there is a difference in the results of front somersault skills between the experimental group using wire steel and the control group not using aids but not significantly.
\end{abstract}

Keywords: effectiveness test, forwarding somersault skills, tools.

\section{Introduction}

Learning is one of the main imperatives in completing the Tri Dharma of Higher Education. Learning is a combination that is arranged inhumanely, equipment, facilities, procedures that affect each other in achieving learning objectives[1] Besides learning is interpreted as teacher activities that are programmed in instructional design, to make students active learning, which emphasizes the provision of learning resources. Teaching can be viewed from many perspectives. The perspective teachers take when they look at the teaching-learning process determines what they will look at in that process and how they will look at it. Perspectives are important because they cause the teacher to see things in certain ways[2]. Some of the above understanding, can be denied from learning as a process of lecturer perspective in seeing things in a certain way in the process of interaction between students and lecturers and learning resources to exchange information. Learning in physical education is essentially in a learning process that requires physical learning to produce holistic changes, these changes are needed through a theory of motion learning that includes cognitive stages,

associative stages, and autonomous stages to achieve physical education goals. The goals of physical education are three psychomotor, cognitive, and affective domains[3]. 
Learning gymnastics floor, in which there are many obstacles that are often encountered including learning difficulties experienced by students to learn basic techniques to complex techniques, in addition to the lack of courage of students in doing the task of movement[4] Learning difficulties are conditions that cause obstacles in one's learning process that result in failure in achieving learning goals [5]. When learning the movement skills of students must understand the concept of movement first[6]. If you have not mastered the task of motion that must be done, the lecturer must help until students understand and are able to practice the movement. Another obstacle found in gymnastic learning is the lack of tools to support the safety factor and the provision of assistance during the learning process. In line with the above opinion[7] stated when teaching gymnastics, things to consider are security and safety. In addition, the end result of the teaching process is the high ability of students to be able to learn easily and effectively[8].

In reality in the field, to achieve effective gymnastics learning is not enough to use the method alone. Aids are needed or effective learning media in delivering learning material. Learning aids in the learning process can arouse new desires and interests, generate motivation and stimulation of learning activities, and even bring psychological influence on students. The use of instructional media at the learning orientation stage will greatly assist the effectiveness of the learning process and the delivery of messages and content at the time[9]. Based on research that had been carried out the previous year, researchers tried to develop aids for front somersault skills. The results achieved in previous studies are the creation of aids made from a series of outdoor tools such as carabiners, webbing, pulleys, steel wires, and hardness designed to facilitate the learning process in gymnastics courses. The tool that was created was the result of expert evaluations in the preparation of initial products which were then tested on a limited scale. Limited trials were carried out on 12 subjects namely Physical Education students at Siliwangi University, extensive trials were conducted on subjects as many as 30 physical education students with different classes from small scale pilot classes assuming the subjects came from different schools. The purpose of this development research is to see the effectiveness of the products that have been developed in the previous year for students of Physical Education at Siliwangi University. Effective or not a product, can be seen from student learning activities and student learning outcomes.

\section{Methods}

The method used in this study is the Quasi Experiment research method. According to [10] the experiment is most powerfull quantitative research method for establishing cause and effect relationships between two or more variable. The most commonly used quasi-experimental design in educational research is the nonequivalent controlgroup design. In this design, reserch participants are not randomly assigned to the experimental and control groups. Experimental research is the most conclusive scientific method. Because the researchers actually set different treatments and then study their effects, the results of this type of research tend to lead to most clear interpretations[11]. Next opinion[12] adding experimental research can be interpreted as a research method used to look for the effect of certain treatments on others under con- 
trolled conditions. Quasi experimental design is used because in reality it is difficult to get a control group used for research. The research design used in this study is nonequivalent control group design. This study uses two groups, namely the experimental group and the control group. Both groups were given a pretest. The experimental group was then given treatment using steel wire aids for front somersault skills, while the control group was given conventional learning. At the end of the treatment the researcher conducted a post-test given to the experimental group and the control group. The design of this study is illustrated in the table below,

Table 1. Nonequivalent Control Group Design

\begin{tabular}{llll}
\hline Group & Pretest & Treatment & Posttest \\
\hline Eksperimental & $\mathrm{O}_{1}$ & $\mathrm{X}$ & $\mathrm{O}_{2}$ \\
Control & $\mathrm{O}_{3}$ & - & $\mathrm{O}_{4}$ \\
\hline
\end{tabular}

Information :

$\mathrm{O}_{1}$ : Pretest eksperimental group

$\mathrm{O}_{2}$ : Posttest eksperimental group

$\mathrm{O}_{3}$ : Pretest control group

$\mathrm{O}_{4}$ : Posttest control group

$\mathrm{X}$ : Learning using tools

The population in this study was the 2017 Physical Education students consisting of 5 classes. The sampling technique uses simple random sampling which is to choose one class that is determined randomly. The class that was sampled in this study was class $1 \mathrm{~A}$, amounting to 38 people. Of the 38 samples divided into two groups not chosen randomly, namely 19 people in the experimental group, and 19 people in the control group. The data processed in this study is a test of learning outcomes of front flip skills. The instrument used in this study used a front somersault skill test that had been tested and validated by experts in previous studies. Indicators of front salto skills can be seen in the following table,

Table 2. Front Somersault Skill Instrument

\begin{tabular}{lll}
\hline Dimension & Indicator & Score \\
\hline \multirow{2}{*}{ Prefix } & - Perfect stand \\
& - Begins by running a few steps \\
\hline & - Resist with both ends of the foot and tight \\
& - Both arms are straight and flanking the ears \\
& - Refuse to reach the highest point \\
Implementation & - Roll in the air (head bent, arm holding knees, \\
& - harmonious rotation) \\
& After turning $360^{\circ}$ both hands are released from the knee, \\
\hline \multirow{3}{*}{ Suffix } & - Landing with both feet tight \\
& - Knees slightly bent \\
& - Both hands stretched out to the front side to maintain \\
& balance \\
\hline & JUMLAH SKOR \\
\hline
\end{tabular}


Description of the rating scale :

1 poin:

Correct performance; proper mechanics, executed in good form. The performer shows balance, control, and amplitude in motion,

0,75 poin:

Average performance; errors seen in mechanics or form; might indicate a lack of balance, control, or amplitude in motion,

\section{0,50 poin:}

Bad appearance; errors in mechanics and form. The performer shows a slight balance, control, or amplitude in motion,

\section{0,25 poin:}

Incorrect or nonexistent performance; igniting mechanics or deformity; there is no display of balance, control, or amplitude in motion.

The data of this study were analyzed quantitatively using statistical analysis techniques, namely using the normality test and homogeneity test. After the results obtained are normal and homogeneous, followed by t-test: Two-Sample Assuming Unequal Variances to test the research hypothesis.

\section{Results and Discussion}

During the learning process, the lecturer acts as a facilitator and guides the process of using steel wire aids for front flip skills. The lecturer gives instructions related to the task movement that will be carried out starting with conveying the theory and concept of front flip material. After that the lecturer gave a demonstration both in the use of tools and ways to help the movement. During the learning process students enjoy the process and discover learning experiences, with the use of steel wire aids, students are helped in learning the task of motion. The fear of doing complex movements can be overcome with these steel wire aids. The results of interviews with students, the effect of the use of these aids for students, which can increase the will power and motivation of students in learning the front flip movement besides student confidence can be increased because of a belief in safety and comfort in doing the movement. From the learning results obtained data as follows,

Table 3. Learning Outcomes

\begin{tabular}{llll}
\hline \multirow{2}{*}{ Group } & $\mathrm{n}$ & \multicolumn{2}{l}{ Average } \\
\cline { 3 - 4 } & & Pretest & Posttest \\
\hline Eksperimen & 19 & 52,63 & 57,89 \\
\hline Control & 19 & 52,58 & 54,68 \\
\hline
\end{tabular}

In accordance with the above statement of the writer that learning in physical education, especially learning gymnastics, is essentially a learning process that 
utilizes physical activity to produce holistic change. The holistic meaning is related to the learning process so the psychomotor, cognitive, and affective aspects of students are achieved. Achieving goals in the learning process is influenced by innovative and quality learning processes so that students get a meaningful learning experience. It is better for lecturers or instructors to create or provide tools in an effort to accelerate the learning process so that the objectives of the learning process can be achieved properly. The data of front somersault skills obtained were analyzed through normality test and homogeneity test followed by t test: Two-Sample Assuming Unequal Variances, as in the table below,

Table 4. Normality test

\begin{tabular}{lllllll}
\hline Group & $\mathrm{n}$ & $\mathrm{Var}$ & $\mathrm{SD}$ & $\mathrm{L}_{0}$ & $\mathrm{~L}_{\mathrm{t}}$ & Result \\
\hline Eksperimen & 1 & 239,43 & 15,47 & 0,1285 & 0,19 & Norma \\
$\mathrm{t}$ & 9 & 3 & 4 & 1 & 5 & 1 \\
\multirow{2}{*}{ Control } & 1 & 127,33 & 11,28 & 0,1287 & 0,19 & Norma \\
& 9 & 9 & 4 & 7 & 5 & 1 \\
\hline
\end{tabular}

From the normality test data above, obtained Lo count $(0.12851)$ from the experimental group with Lo table (0.195). Lo count $(0.12877)$ from the control group with Lo table (0.195). The conclusion is that the samples in the experimental and control groups are normally distributed. Then the data analysis is continued with the homogeneity test or the F test as in the table below,

Table 5. Homogeneity test

\begin{tabular}{llllll}
\hline Group & df & Var & F hit & F tab & Result \\
\hline Control & 18 & 127,339 & 1,880 & 0,45102 & Homogen \\
Eksperimen & 18 & 239,433 & 3 & & \\
\hline
\end{tabular}

The results of the $\mathrm{F}$ test above, obtained an $\mathrm{F}$ count of (1.8803) is greater than the $\mathrm{F}$ table of (0.45102), thus it can be concluded that the sample for this study is Homogeneous. After obtaining the value of F, then do the $t$ test: Two-Sample Assuming Unequal Variances with the aim to compare the average of two groups that are not paired with each other or not related to each other, or two different sample subjects. As in the table below,

Table 6. $t$ Test : Two-Sample Assuming Unequal Variances

\begin{tabular}{lll}
\hline & Variable 1 & Variable 2 \\
\hline Mean & 57,89474 & 54,68421 \\
Variance & 239,4327 & 127,3392 \\
Observations & 19 & 19 \\
$\begin{array}{l}\text { Hypothesized Mean } \\
\text { Difference }\end{array}$ & 0 & \\
df & 33 & \\
t Stat & 0,730727 &
\end{tabular}




$$
\begin{array}{ll}
\mathrm{P}(\mathrm{T}<=\mathrm{t}) \text { one-tail } & 0,235051 \\
\text { t Critical one-tail } & 1,69236 \\
\mathrm{P}(\mathrm{T}<=\mathrm{t}) \text { two-tail } & 0,470103 \\
\text { t Critical two-tail } & 2,034515
\end{array}
$$

From the results of the statistical analysis of the above hypothesis test, obtained $\mathrm{t}$ count $(0.730727)<$ from t table (2.034515) which means that Ho was accepted and H1 was rejected, so it was concluded that there were differences in the results of front somersault skills between the experimental groups using assistive devices with control group that does not use assistive devices but not significantly.

\section{Conclusion}

Experimental research that has been carried out is a follow-up study from the previous year about the development of tools (steel wire) for front somersault skills. Based on the results of the statistical analysis of the hypothesis test using the t-test, the results of the effectiveness test in this study showed the ineffectiveness of the tools steel wire used for front somersault skills. It is assumed that there are several factors that influence the results of this study, such as being less objective and less consistent in assessing front somersault skills in order to obtain less authentic scores. However, if seen from the results of the pretest and posttest as well as the psychological point of view of students there is an increase in movement skills. In addition, the learning process produces psychological changes, that is, students feel comfortable and safe when using steel wire aids and are able to increase student motivation in learning task assignments. Based on the analysis of the results of the $t$ test results in the experimental group and the control group, it showed that there were differences in the results of the front somersault skills using steel wire aids but not significantly with the $t$ value $(0.730727)<$ from the $t$ table $(2.034515)$.

The results of the research carried out have similarities with other studies namely, such as research results[13] with the results of the pretest and posttest: (a) return board products have effectiveness and can be used to improve forehand for table tennis topspin for beginners 53\%, and for advanced groups $32 \%$, (b) return board products can be used as training tools for junior, beginner and senior level table tennis athletes, (c) return board products can be used as a means of motivating athletes to practice by measuring the ability of each athlete's topspin forehand. In line with the results of the above research[14] mention; (a) based on the validation of experts and the results of the trial, a front handspring skill test model product for overall gymnastics athletes is suitable for use (b) based on the results of small group trials, and field trials can be stated that products in the form of front skills tests Handspring is valid and suitable for use. Besides the results of research[15] the creation of a futsal ball thrower that has been tested for effectiveness and serves to hone the capabilities of various futsal ball game techniques. The expected results of research are to help the world of futsal sports in Indonesia so that it triggers the emergence of new technological ideas and tools in the future. 
The equation of the research results lies in the product being developed in the form of a tool that is tested for the effectiveness of the product to be used in terms of improving performance, especially in the branch of gymnastics and is beneficial for all people. The difference in results from the research conducted is, in several other studies focus on the development of gymnastic assessment instruments, as well as the development of tools for techniques that are fairly basic in certain sports. The advantage of this research is the creation of tools that can be used to help techniques that are classified as both complex in achievement gymnastics and educational gymnastics. The resulting product is beneficial for teachers, lecturers, and even trainers. However, the results of effectiveness tests in this study need to be reviewed and re-examined for the future by rearranging the product design that was developed, and involving experts or judges when conducting assessments when collecting data in the field.

\section{Acknowledgements}

We would like to thank Siliwangi University, Indonesia for the funding.

\section{References}

[1] Hamalik O. Proses Belajar Mengajar. Bumi Aksara. Bandung.; 2003.

[2] Mudjiono D dan. Belajar dan Pembelajaran. Rineka Cipta. Jakarta; 2006.

[3] Rink JE. Teaching Physical Education for Learning. The McGraw-Hill Companies, Inc.; 2014

[4] Buck, M. M., Jable JT. Introduction to Career in Health, Physical Education, and Sport. Wadsworth: Thomson Learning.; 2004

[5] Gunawan, S., Millah, H., \& Mulyana FR. Development of Tools for Forwarding Somersault Skills. J Phys Educ Sport [Internet]. 2018;7(3):200-7. Available from: https://journal.unnes.ac.id/sju/index.php/jpes/article/view/26296.

[6] Hakim T. Belajar Secara Efektif. Panduan Menemukan Teknik Belajar, Memilih Jurusan, dan Menentukan Cita-cita. Jakarta : Puspa Swara; 2001.

[7] Gunawan, S., Millah, H., \& Mulyana FR. Development of Tools for Forwarding Somersault Skills. J Phys Educ Sport [Internet]. 2018;7(3):200-7. Available from: https://journal.unnes.ac.id/sju/index.php/jpes/article/view/26296

[8] Hakim T. Belajar Secara Efektif. Panduan Menemukan Teknik Belajar, Memilih Jurusan, dan Menentukan Cita-cita. Jakarta : Puspa Swara; 2001.

[9] Restian A. Psikologi Pendidikan Teori \& Aplikasi. Malang: UMM. Press.; 2015.

[10] Ward, Philip \& Lehwald H. Effective Physical Education Content and Instruction. Human Kinetics.; 2018.

[11] Hariyanto S\&. Belajar dan Pembelajaran: Teori dan Konsep Dasar. Bandung: Remaja Rosdakarya.; 2016.

[12] Hasanah A. Pengaruh Latihan Alat Bantu Matras Miring Dan Matras Datar Terhadap Hasil Belajar Roll Belakang. 2016;

[13] Meredith D. Gall, Walter R. Borg JPG. Educational Research. Allyn \& Bacon. Pearson Education, Inc.; 2003.

[14] Fraenkel JR. How to Design and Evaluate Research in Education. McGraw-Hill, a business unit of The McGraw-Hill Companies, Inc; 2012.

[15] Sugiyono. Metode Penelitian. Kuantitatif, Kualitatif dan R\&D. Alfabeta; 2016. 
[16] Santosa T; S. Pengembangan AlatBantu Return Board Untuk Forehand Topspin Tenis Meja. J. Pedagog Olahraga [Internet]. 2016;2(2):30-48. Available from: https://jurnal.unimed.ac.id/2012/index.php/jpor/article/view/4513

[17] Handayani SG. Pengembangan Instrumen Tes Keterampilan Front Handspring Atlet Senam Lantai. J Sains Keolahragaan Kesehat. 2018;3(1):23-6.

[18] Syakur, Mohamad Abdul; Badruzaman; Paramitha ST. Pengembangan Alat Bantu Latihan Pelontar Bola Futsal Berbasis Mikrokontroler dengan Menggunakan Software Pemograman Arduino. J. Terap Ilmu Keolah. 2017;2(1):29-32. 